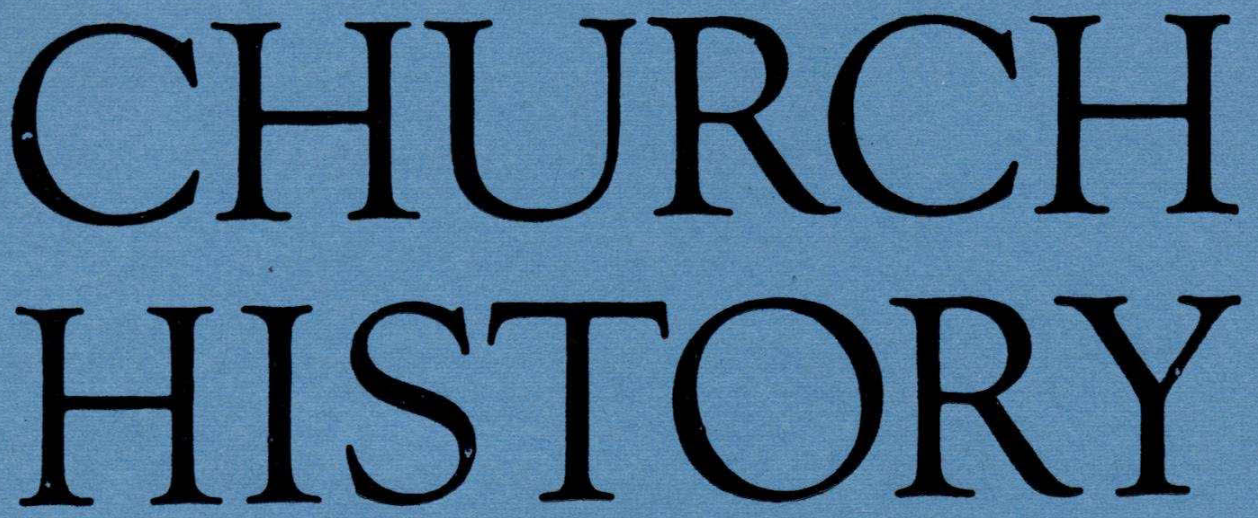

JUNE, 1951

The Finnish Church and Russian

Imperialism

T. A. Kantonen

Objectives and Achievements of the Liturgical

Movement in the Roman Catholic Church

Since World War II

Ernst B. Koenker

The Pietist and Puritan Sources of Early

Protestant World Missions. (Cotton

Mather and A. H. Francke)

Ernst Benz

Learning in Austria About 1300 - Notes

and Suggestions George Bingham Fowler

Clement of Alexandria on the Generation of the Logos

H. A. Wolfson

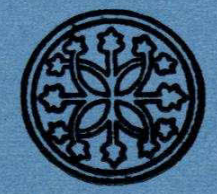

Published by

THE AMERICAN SOCIETY OF CHURCH HISTORY 


\section{THE AMERICAN SOCIETY OF CHURCH HISTORY}

Founded By Philip Schaff, 1888: Reorganized, 1906; Incorporated by ACt Of The Legislature of New York, 1916.

\section{OFFICERS FOR 1951}

RAY C. Petry President Sandford Flfming .... Vice-President RAymond W. Albright .... Secretary (1524 Palm Street, Reading Pa.)
M. M. DEEMS ... Assistant Secretary GuY S. KLETT ................ Treasurer Wilhelm PaUCK? J. H. NichoLs Editors

\section{OTHER MEMBERS OF THE COUNCIL}

KENNETH S. LATOURETTE Matthew Spinka ERNEST W. SchWIEbert WiNTHROP S. HuDSON
MASSEY H. SHEPHERD

SIDNEY E. MEAD

CARL E. Schneider

L. J. TRINTERUd

Church History is a quarterly journal published in March, June, September, and December by the American Society of Church History. The editorial address is Swift Hall 306, The University of Chicago, Chicago 37, Illinois.

Subscription prices are four dollars a year, one dollar and a quarter for single copies. Twenty-five cents a year should be added for foreign countries. Remittances should be made to the order of the American Society of Church History. Subscriptions, renewals, changes of address, claims for missing numbers, orders for single copies of current or back issues should be addressed to Guy S. Klett, Presbyterian Historical Society, 520 Witherspoon Building, Philadelphia 7 , Pennsylvania. Claims for missing numbers will be honored without charge if made within within two months following the regular month of publication.

The articles in Church History are indexed in the International Index of Periodicals.

Microfilm reproductions of CHURCH HistoRy, beginning with Volume XVIII, are available to subscribers and to members of the Society from University Microfilms, 313 North First Street, Ann Arbor, Michigan.

The Publication Office is in Berne, Indiana.

Entered as second class matter March 9, 1934, at the post-office at Berne, Indiana, under the Acts of March 3, 1879. 


\section{CHURCH HISTORY}

Edited By J. H. Nichols and Wilhelm PAUCK

University of Chicago

with the cooperation of

Roland Bainton (Divinity School, Yale University)

R. Pierce Beaver (Missionary Research Library)

RoBert GRANT (Theological Faculty, University of the South)

Winthrop S. Hudson (ColgateRochester Divinity School)
Sidney F. Mead (Divinity School, University of Chicago)

Ray C. Petry (Divinity School, Duke University)

Matthew Spinka (Hartford Theological Seminary)

L. J. Trinterud (McCormick Theological Seminary)

Vol. XX

June, 1951

No. 2

\section{TABLE OF CONTENTS}

The Finnish Church and Russian Imperialism

T. A. Kantonen

Objectives and Achievements of the Liturgical

Movement in the Roman Catholic Church

Since World War II

Ernest B. Koenker

The Pietist and Puritan Sources of Early Protestant

World Missions. (Cotton Mather and A. H.

Francke)

Ernst Benz

Learning in Austria About 1300 -- Notrs and

SugGestions

George Bingham Fozeler

Chement of Alexandria on the Generation

OF THE LoGos

H. A. Wolfson 


\section{CONTENTS}

Book Reviews:

Westin, Gunnar: Kyrkohistorisk àroskrift Edgar M. Carlson

Williams, R. R. : Authority in the Apostolic Age .... Massey H. Shepherd, Jr. Katz, Joseph : Plotinus' Search for the Good Ralph Marcus

Willis Geoffrey Grimshaw: Saint Augustine and the Donatist Controversy Mervin M. Deems

Beck, Henry G. J.: The Pastoral Care of Souls in Southeast France During the Sixth Century Quirinus Breen

Petry, Ray C.: Preaching in the Great Tradition Paul Scherer

Butler, H. E.: The Chronicles of Jocelin of Brakelond Concerning the Acts of Samson, Abbot of the Monastery of St. Edmund Quirinus Breen

Richardson, Cyril C.: Zwingli and Crammer on the Eucharist E. R. Hardy, Jr.

Riedemann, Peter: Account of Our Religion, Doctrine and Faith Robert Friedmann

Singer, Dorothea W.: Giordano Bruno; His Life and Thought Edwin E. Aubrey

CRAGG, G. R.: From Puritanism to the Age of Reason J. Minton Batten

SheWring, Walter: Letters of Eric Gill F. W. Buckler

Seraphim, Metropolitan: Die Ostkirche Matthew Spinka

Smith, C. Henry : The Story of the Mennonites Robert Friedmann

Olson, Oscar N.: The Augustana Lutheran Church in America G. Everett Arden

Eller, Paul H.: These Evangelical United Brethren, Raymond W. Albright

Drury, CAPT. Cliffrord Merrill: The History of the Chaplain Corps, United States Navy E. G. Homrighausen

Smith, Willard H.: Paraguayan Interlude; Observations and Impressions Robert Friedmann 